\title{
地域学術資料の蓄積と共有を目指した学術資源リポジトリの構築 \\ A Construction of repository for non-Bibliographic Academic Resources
}

\author{
堀井洋 ${ }^{1 *}$, 林正治 ${ }^{2}$, 堀井美里 ${ }^{1}$, 高田良宏 ${ }^{3}$, 山地一禎 ${ }^{4}$, 上田啓未 ${ }^{5}$, 古畑徹 ${ }^{5}$ \\ Hiroshi HORII $^{1 *}$, Masaharu HAYASHI ${ }^{2}$, Misato HORII ${ }^{1}$, \\ Yoshihiro TAKATA ${ }^{3}$, Kazutsuna YAMAJI ${ }^{4}$, Hiromi Ueda ${ }^{5}$, Toru FURUHATA ${ }^{5}$ \\ 1 合同会社AMANE AMANE.LLC \\ 干923-1241 石川県能美市山田町口8 E-mail: \{a-horii|ymisachi\}@amane-project.jp \\ 2 一橋大学 情報基盤センター \\ Center for Information and Communication Technology, Hitotsubashi University \\ 干186-8601 東京都国立市中2-1 E-mail: m-haya@amane-project.jp \\ 3 金沢大学メディア基盤センター Information Media Center, Kanazawa University \\ 干920-1192 石川県金沢市角間町Ｅ-mail: yosihiro@kenroku.kanazawa-u.ac.jp \\ 4 国立情報学研究所 National Institute of Informatics \\ 厂101-8430 東京都千代田区一ツ橋2-1-2Ｅ-mail: yamaji@nii.ac.jp \\ 5 金沢大学資料館 Kanazawa University Museum \\ 干920-1192 石川県金沢市角間町Ｅ-mail: museum@kanazawa-u.ac.jp \\ *連絡先著者 Corresponding Author
}

地域学術資料の分野・組織の垣根を越えた横断的な情報共有を目的として、合同会社 AMANE・金沢 大学・国立情報学研究所・その他の研究者が中心となり学術資源リポジトリの構築を進めている。そ の一環として、明治〜昭和戦前期の技術教育に使用された科学実験機器資料情報の蓄積と共有を目指 しており、本報告では それらを事例として、学術資源リポジトリの機能・人的・社会的な位置づけや 課題等について論じる。

In recent year, social concern about exchanging and sharing of academic resources included non-bibliographic between universities is increasing. However, in actual situation, there are some problems about preservation and digitalization of academic resources. In this paper, a case study of scientific apparatuses since the Meiji era, we discuss about construction of repository for non-bibliographic.

キーワード：非文献資料，学術資料，リポジリ

Keywords: non-bibliographic resources, academic resources, repository 


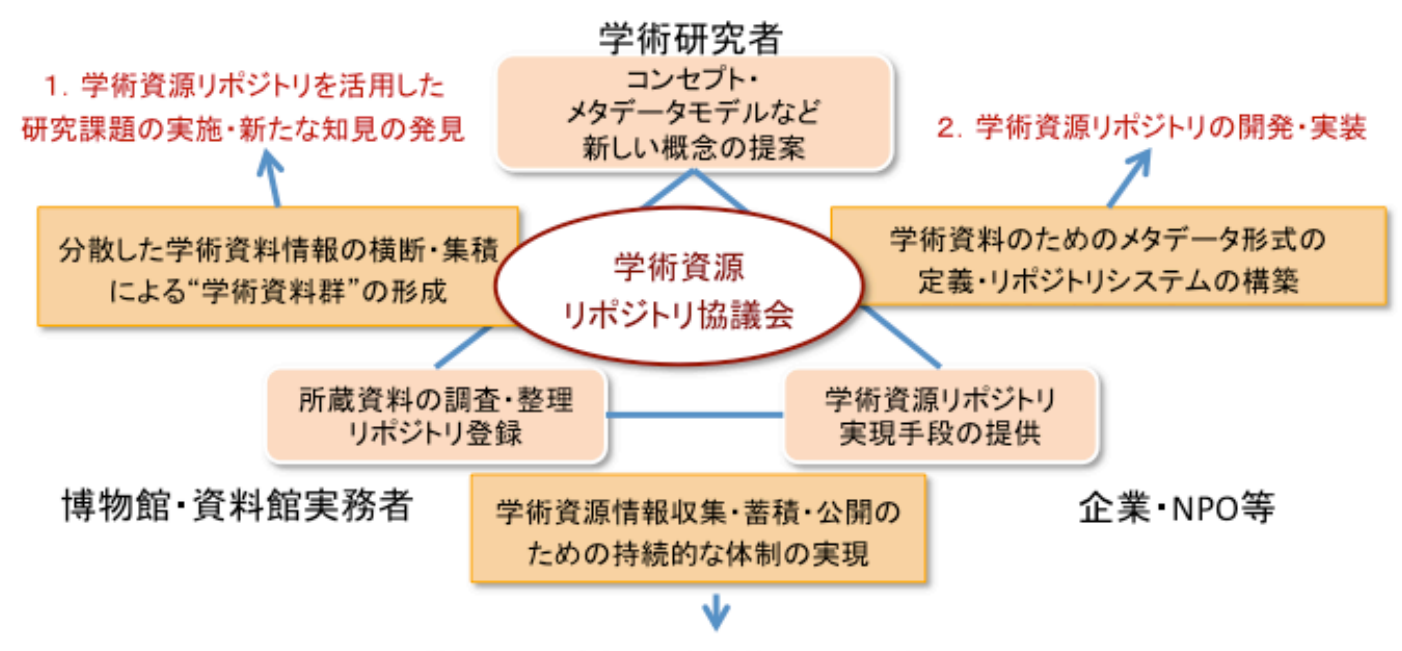

3. 学術資源リポジトリの組織的・システム的な運用・公開

図 1 学術資源リポジトリ協議会の概要

\section{1 はじめに}

大学博物館や自治体などの公共博物館 に所蔵されている文献以外の学術資料 （文献資料との対比として，“非文献資 料”）は，膨大かつ多種多様である。これ ら学術資料の学術分野や所蔵管理組織の 垣根を越えた分野・組織横断的な情報共 有について, 学術成果の公開・共有や学 術資料の保存などの観点から，近年関心 と必要性が高まっている。しかしその一 方で，博物資料などの非文献資料に関し ては，文献横断検索環境に相当する分 野・組織を横断したリポジトリの構築は 実現されておらず，非文献資料情報の取 り扱いについても学術機関間での統一的 な仕組みは，未定義または普及していな いのが現状である。このような状況を鑑 みた場合に，学術資料全般を対象にした 横断的な学術資源リポジトリを実現させ るためには，資料の所在や由来などの詳 細情報（メタデータ）を共通のフォーマ ットに基づいて収集・整理し，ネットワ 一ク上で共有・公開するための情報環境
であるリポジトリの構築など，技術・人 的コミュニティ双方を構築・整備する必 要がある。

本報告では，合同会社 AMANE・金沢大 学・京都大学・国立情報学研究所などの 研究者が中心となり進めている学術資源 リポジトリ協議会の取り組みについて, 明治・大正 ・ 昭和前期の科学実験機器資 料リポジトリ化プロジェクトを事例とし て紹介する。

\section{2 学術資源リポジトリについて}

\section{1 学術資源リポジトリ協議会}

学術資源リポジトリ協議会は, 図 1 に示 すように大学等の学術機関や企業・自治体 などの学術資料の保存・活用に関わる研究 者が中心となり，2011 年に結成された [1]．本協議会では，(1)非文献資料，ある いはリポジトリを研究対象とする研究者, (2)非文献資料の所蔵管理に携わる博物館 学芸員, (3)リポジトリの構築や博物資料の 活用を行う企業・団体職員の三者が連携し て，学術資料に関する情報の組織・分野を 
越えた共有や研究・議論の場の創出を目指 している。

2013 年 4 月現在, 学術資源リポジト リ協議会において公開をしている科学実 験機器資料を以下に記す。

新潟大学所蔵 : 20 点

神戸大学所蔵 : 21 点

東京大学駒場博物館蔵 : 22 点

京都大学総合博物館像：84 点 (公開準 備中）

石川県立自然史資料館蔵：747 点 (公 開準備中)

\section{2 学術資源リポジトリの構築}

学術資源リポジトリの公開環境を国立 情報学研究所が開発したNetCommons + WEKO (Ver. 2.0.1) を利用して構築した [2]. 図 2 に画面外観を示す.リポジトリの実装 に際しては，構築や管理が容易かつ柔軟性 が高いCMS (Contents Management System) であるNetCommons を，リポジトリ部分に ついては国内の文献リポジトリで多くの 実績を有する国産ソフトウェアである WEKOを非文献資料向けにカスタマイズす る方法を採用した。さらに, 非文献資料に 対応した共通メタデータを定義し, 各項目 をネットワーク上の文献等の情報記述を 目的に定義されたDublin Coreメタデータ （以下，DC）へ対応させることを試みた [3]. その理由は以下の 3 点である.

A） DCは共通メタデータ形式として広 く認知されており, 既に文献資料リポジ トリで多く用いられている。

B）独自拡張語彙の定義など, 非文献 資料情報の特性を反映した拡張が可能
である。

C） DCに対応した既存の文献資料リポ ジトリシステムの改修や将来的な文献 資料リポジトリとの情報共有が期待で きる。

2013 年 3 月現在, Dublin Coreを拡 張したメタデータを用いてリポジトリを 運用しているが，既存の文献リポジトリと の親和性が高い反面, メタデータ項目の構 造自体が非文献資料特有の情報記述, 特に 階層的な資料に関寸る情報（例: 生体とし ての生物・その標本・それを写したフィル ムの関係など）を記述するためには，必ず しも十分ではないことが明らかとなって いる. 現在, 非文献資料に適したメタデー タ表現について更なる検討を進めている.

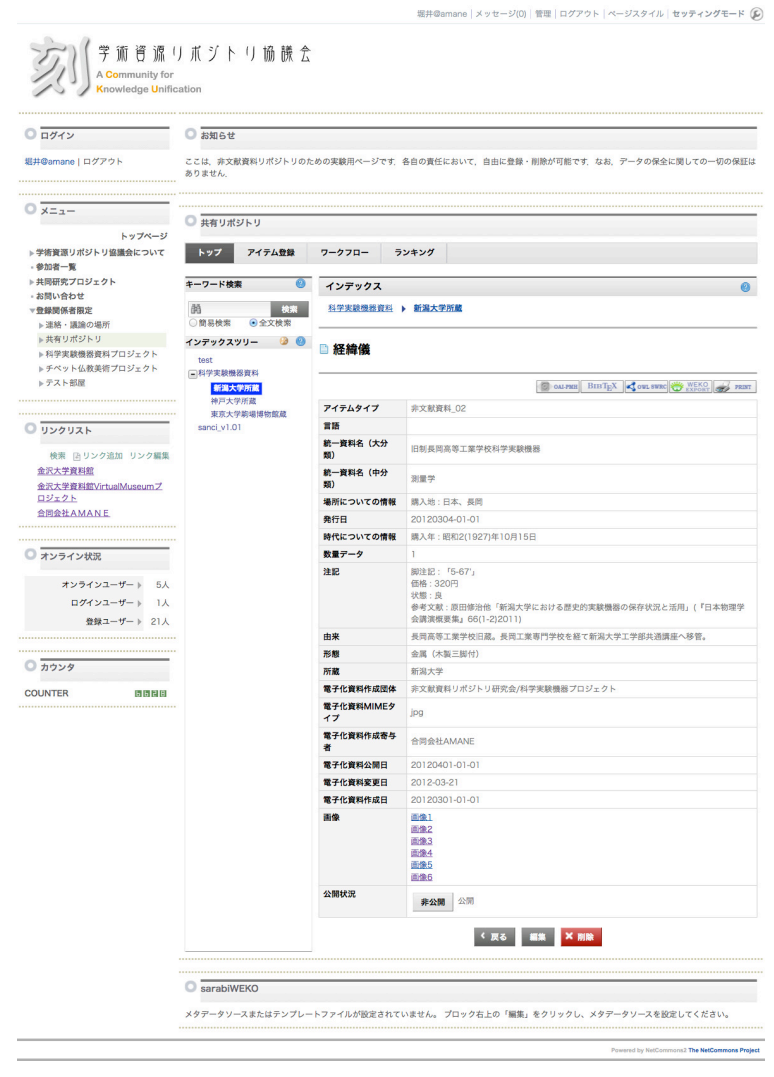

図 2 学術資源リポジトリ Web 画面外観 


\section{3 科学実験機器資料に関する 調查}

\section{1 科学実験機器資料の概要}

明治期以降の科学実験機器資料につい ては,「科学教育機器資料」や「物理実験 機器資料」など, 機器の用途や研究分野に よって複数の呼称が存在するが，本稿では それらを総じて「科学実験機器資料」と称 する。科学実験機器資料は, 明治期に設立 された旧制高等学校・高等工業学校などの 教育機関で, 主として科学教育に使用され た [4][5]。これらは, 日本の科学教育・技 術史の詳細と変遷を理解する上で重要な 学術資料であると同時に, 実験機器の一部 は海外で製作された輸入品であり，当時の 世界的な機械設計思想および加工技術，デ ザイン・装飾の傾向を反映している点も非 常に興味深い。科学実験機器資料は，金沢 大学（旧制第四高等学校）京都大学（旧制 第三高等学校）をはじめとする全国の各大 学に所蔵されていることが先行研究によ り明らかとなっている。しかし，その詳細 な現存状況について, 物理学 ・ 心理学など の研究分野, または所蔵機関を横断して総 合的・俯瞰的に解明する試夕はごく僅かで ある $[6]$ 。

\section{2 所蔵概要の調査と分析について}

学術資源リポジトリを活用した学術研 究事例として, 科学実験機器資料の所蔵機 関を横断した調查と分析を紹介する. 本調 査では, 以下に示す代表的な 13 種類の科 学実験機器資料を選定し, 旧制高校を前身 校とする大学機関等の協力を得て所在調 查を実施した。

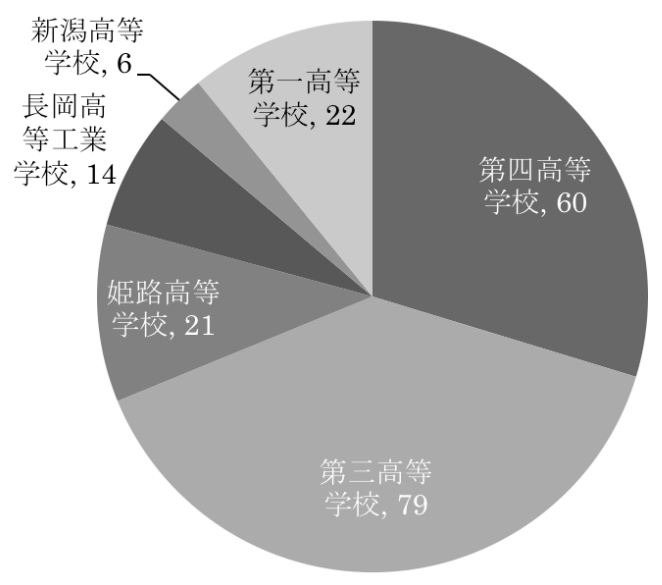

図 3 科学実験機器資料 13 種類の 現存状況

\section{$<13$ 種類の機器資料 $>$}

光の再合成器 $\cdot$ 顕微鏡・立体鏡・ウィム ズハースト静電起電機・六分儀・トラン シット・ウィルソン霧箱・分光器・ジャ イロスコープ・マグデブルグ半球・クー リッジ管・エアリーの複振子・電信機

＜調查対象機関＞（）内は前身校 東京大学（旧制第一高等学校） 京都大学（旧制第三高等学校） 金沢大学・石川県立自然史資料館 （旧制第四高等学校） 神戸大学（旧制姫路高等学校） 新潟大学（旧制新潟高等学校・ 旧制長岡工業高等学校)

本調査結果の一部（科学実験機器資料 1 3 種類の現存点数）について図 3 に示す. これらの結果から，第四高等学校と第三高 等学校の科学実験機器資料が最も多く現 存していることが明らかとなった。その理 由として，金沢・京都ともに，戦災や地震 などの自然災害の影響をあまり受けてい 
ないことが推測される.

\section{4 まとめ}

本報告で紹介した学術資源リポジトリ 協議会の意義・特徵は，“資料所蔵機関” が “資料公開機関”を兼衫ることが一般的 であった従来からの学術資料情報公開を， 独立した組織において実施する点にある。 国内には，大学・自治体・民間組織など博 物館やそれに類する多くの学術資料所蔵 機関が存在し, 多様な学術資料が多数所蔵 されているが，資料情報の電子的な公開は 進んでいない，その主たる理由を以下のよ うに推測する.

(1)[システムの構築・管理]リポジトリな ど学術資料情報の公開を実現するシステ ムの構築・管理に要する費用や人員の負 担が大きい。

(2) [学術データ生成・記述]学術資料に関 するメタデータや画像などデータ生成に 要するコストや手段（共有のメタデータ 形式など）がそしい。

(3) [社会的な役割・理解]電子的な学術資 料情報の公開が所蔵施設・機関の本来業 務として位置づけられていない。

これらの現状を考えた場合には, 横断的 かつ共通的な “学術資料情報蓄積 - 公開手 段”としての学術資源リポジトリと, その “受け具・普及媒体”としての学術資源り ポジトリ協議会の試みは, 単なる技術的な 新規性のみではなく, 学術情報の公開に関 する意義や役割をあらためて問うもので ある。しかしその一方で現実には，学術資 料情報に関する権利や情報保護・公開範囲 の限定など，様々な学術資料情報に関する 諸課題が山積している。これらを踏まえ，
今後も学術資源リポジトリ協議会の活動 を継続していく所存である。

\section{謝辞}

本研究の一部は, 科研費 (基盤研究 (B) 24300310)の支援を受けて行われた. 関係者のみなさまに感謝します。

\section{参考文献}

[1］学術資源リポジトリ協議会 http://amane-project.jp/hibunken/, (2013 年 4 月 19 日参照)

[2] 学術資源共有基盤, 国立情報学研究 所, http://weko.at.nii.ac.jp/,

(2013 年 4 月 19 日参照)

[3] The Dublin Core Metadata Initiative, DCMI, http://dublincore. org/,

(2013 年 4 月 19 日参照)

[4] 板垣英治：「石川県専門学校の化学教 育」, 日本海域研究 36 号, 2005.

[5] 竹村松男：「保存された四高物理機器 付. 学制確立初期の物理教育事情」, 金沢 大学資料館紀要 4-1-24, 2006.

［6］永平幸雄; 川合葉子編著：「近代日本と 物理実験機器」, 京都大学学術出版会, 2001 